\title{
Automated closed-loop control of diabetes: the artificial pancreas
}

\author{
Boris Kovatchev (D)
}

\begin{abstract}
The incidence of Diabetes Mellitus is on the rise worldwide, which exerts enormous health toll on the population and enormous pressure on the healthcare systems. Now, almost hundred years after the discovery of insulin in 1921, the optimization problem of diabetes is well formulated as maintenance of strict glycemic control without increasing the risk for hypoglycemia. External insulin administration is mandatory for people with type 1 diabetes; various medications, as well as basal and prandial insulin, are included in the daily treatment of type 2 diabetes. This review follows the development of the Diabetes Technology field which, since the 1970s, progressed remarkably through continuous subcutaneous insulin infusion (CSII), mathematical models and computer simulation of the human metabolic system, real-time continuous glucose monitoring (CGM), and control algorithms driving closed-loop control systems known as the "artificial pancreas" (AP). All of these developments included significant engineering advances and substantial bioelectronics progress in the sensing of blood glucose levels, insulin delivery, and control design. The key technologies that enabled contemporary AP systems are CSII and CGM, both of which became available and sufficiently portable in the beginning of this century. This powered the quest for wearable home-use AP, which is now under way with prototypes tested in outpatient studies during the past 6 years. Pivotal trials of new AP technologies are ongoing, and the first hybrid closed-loop system has been approved by the FDA for clinical use. Thus, the closedloop AP is well on its way to become the digital-age treatment of diabetes.
\end{abstract}

Keywords: Diabetes, Hypoglycemia, Hyperglycemia, Continuous glucose monitoring (CGM), Insulin pumps, Continuous subcutaneous insulin infusion (CSII), Artificial pancreas (AP), Closed-loop control

\section{Background}

On March 6, 2013, the American Diabetes Association (ADA) published research showing that the total costs of diagnosed diabetes in the U.S. have risen to $\$ 245$ billion in 2012 from $\$ 174$ billion in 2007, a 41\% increase over 5 years (American Diabetes Association 2013). Thus, diabetes is a prime example of an enormous health care problem the only solution of which is integration of behavioral change, advanced bioengineering aiming functional replacement of the failing beta cell, and synergistic drug-device integration. Given that diabetes is common and affecting millions of people around the world, major efforts target the optimization of diabetes control and large international organizations are dedicated to the treatment and, ultimately, the cure of diabetes and its complications, including: ADA (American Diabetes

Correspondence: boris@virginia.edu

Center for Diabetes Technology, University of Virginia, P.O. Box 400888,

Charlottesville, VA 22908, USA

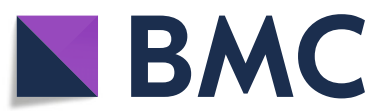

Association [Internet] n.d.), the European Association for the Study of Diabetes (EASD, ( n.d.)), the International Diabetes Federation (IDF, (2014)), and the Diabetes Technology Society (Diabetes Technology n.d.). These efforts are picking up speed and new diabetes treatment technologies are being introduced daily. To put this progress in perspective, for the 1,900 years following the clinical introduction of the term diabetes (Aretaeus the Cappadocian, first Century AD) diet was the only treatment (albeit unsuccessful in type 1 diabetes). In the nineteenth century, the nature of diabetes was generally understood, and with the discovery of insulin in 1921 by Frederick Banting at the University of Toronto type 1 diabetes was no longer a death sentence. For this breakthrough, Banting and John Macleod were awarded the Nobel Prize in Physiology or Medicine in 1923. To recognize the contributions of their colleagues, Banting shared his prize with Charles Best and Macleod shared his with J.B. Collip.

(c) The Author(s). 2018 Open Access This article is distributed under the terms of the Creative Commons Attribution 4.0 International License (http://creativecommons.org/licenses/by/4.0/), which permits unrestricted use, distribution, and reproduction in any medium, provided you give appropriate credit to the original author(s) and the source, provide a link to the Creative Commons license, and indicate if changes were made. The Creative Commons Public Domain Dedication waiver (http://creativecommons.org/publicdomain/zero/1.0/) applies to the data made available in this article, unless otherwise stated. 
Several subtypes of diabetes are identified, most prevalent of which are referred to as type 2 diabetes (over $90 \%$ of the people with diabetes) and type 1 diabetes an auto-immune disorder in which the immune system targets its own $\beta$-cells in the islets of Langerhans of the pancreas - the site of insulin secretion and synthesis. Type 1 diabetes is characterized by absolute deficiency of insulin secretion, which necessitates daily (or continuous) external insulin injections to maintain carbohydrate metabolism and sustain life. Most often, type 1 diabetes occurs in childhood and adolescence (although it can occur at any age) and, until recently, was also known as "Insulin-Dependent Diabetes Mellitus (IDDM)" or "Juvenile Diabetes." Type 2 diabetes results from a combination of impaired insulin action and insufficient $\beta$-cell function. In health, the $\beta$-cell secretes insulin in response to increase in blood glucose (BG) levels (e.g. after meals) or to elevated ambient BG. When insulin secretion is inadequate and cannot overcome the insulin resistance occurring as a result from obesity or other factors, hyperglycemia (elevated blood sugar levels) would occur. The progression of type 2 diabetes is typically gradual, beginning with pre-diabetes, i.e. impaired fasting glucose (IFG) and impaired glucose tolerance (IGT). People with type 2 diabetes are also more likely to have comorbidities, including as cardiovascular risks such as dyslipidemia and hypertension. Overall, both type 1 and type 2 diabetes require daily treatment to match insulin availability to carbohydrate intake. In type 1 diabetes this is exclusively achieved by exogenous insulin injection; in type 2 diabetes, a variety of medications are available to lower insulin resistance or amplify any residual insulin secretion; basal and prandial insulin injections are increasingly used as well.

Understanding and quantifying the dynamics of the human glucose-insulin control network is critical for the technological treatment of diabetes. BG levels are raised by food containing carbohydrates, and glucose is also produced by the body (mainly by the liver), after which it is distributed and utilized through both insulin-independent (e.g. central nervous system and red blood cells) and insulin-dependent (muscle and adipose tissues) pathways. Insulin secreted by the pancreatic $\beta$-cell is the primary regulator of glucose homeostasis. If a BG perturbation occurs (e.g. after a meal containing carbohydrates), beta-cells secrete insulin in a direct response to the increase in BG concentration, or as an indirect response to hormonal release from the gut (GIP and GLP-1, known as the "incretin effect" (Nauck et al. 1986a)). In turn, insulin signaling promotes glucose utilization and inhibits glucose production to bring rapidly and effectively plasma glucose to its pre-perturbation level (Cobelli et al. 2009). In pathophysiology, this feedback control is degraded. In type 2 diabetes, the glucose control network is largely preserved, but insulin secretion is deficient relative to hepatic and peripheral insulin resistance. In particular, the incretin response is deficient (Nauck et al. 1986b), and this finding triggered the introduction of new classes of medications known as GLP-1 receptor agonists (incretin mimetics), and DPP-4 inhibitors (incretin enhancers) (Drucker and Nauck 2006). In type 1 diabetes, insulin secretion is virtually absent, while glucagon secretion from the $\alpha$-cell is still preserved, which removes the insulin-dependent pathways lowering BG levels and therefore BG can only go up, leading to hyperglycemia. Thus, insulin replacement is mandatory. In both type 1 and type 2 diabetes, a battery of counterregulatory hormones are also at work, including glucagon, epinephrine, cortisol and growth hormone, which defend the body against life-threatening low blood sugar events (i.e. severe hypoglycemia).

\section{The optimization problem of diabetes}

Classic large-scale studies have shown that intensive treatment to maintain optimal average glycemia (as measured by Hemoglobin A1c) markedly reduces the chronic complications in both type 1 (Reichard and Phil 1994; The Diabetes Control and Complications Trial Research Group 1993) and type 2 diabetes (UK Prospective Diabetes Study Group (UKPDS) 1998). External insulin replacement through multiple daily injections (MDI) or continuous subcutaneous insulin delivery (CSII) using insulin pumps, is mandatory in type 1 diabetes and is increasingly used in type 2 diabetes. However, MDI and CSII are not nearly as efficient as the endogenous insulin secretion; as a result, acute events do occur, exposing patients to severe hypoglycemia or diabetic ketoacidosis. Imperfect intensive insulin treatment may also reduce the warning symptoms and hormonal defenses against hypoglycemia leading to defective counterregulation and hypoglycemia unawareness (White et al. 1983; Cryer and Gerich 1985; Amiel et al. 1987; Amiel et al. 1988); thus, intensive treatment may trigger severe hypoglycemia (Gold et al. 1993; Henderson et al. 2003; Lincoln et al. 1996; The Diabetes Control and Complications Trial Research Group 1997). As a result, hypoglycemia has been identified as the primary barrier to optimal glycemic control (Cryer 1994; Cryer et al. 2003; Cryer 2014) and, years ago, the treatment of diabetes was clearly formulated as a "trade-off between glycemic control and iatrogenic hypoglycemia" (Cryer 2014). This means that lowering hemoglobin A1c - the primary marker of average glycemic control - must be accompanied by concurrent mitigation of the risk for hypoglycemia. Consequently, people with diabetes face a life-long optimization problem: to maintain strict glycemic control and reduce hyperglycemia, without increasing their risk for hypoglycemia. BG level is both the measurable 
result of this optimization and the principal feedback signal to the patient for his/her control of diabetes. This understanding of the diabetes optimization objectives led to quantitative description of the glucose-insulin control network, modeling, simulation and, ultimately, to bioengineering control of diabetes (Cobelli et al. 2009). It should be noted, however, that undesirable glycemic variation is triggered at multiple biosystem levels and is driven by self-treatment behavior. Translated to the context of contemporary diabetes technologies, such as Continuous Glucose Monitoring (CGM), Advisory Systems, or Artificial Pancreas (AP), this concept helps define a treatment ecosystem that includes several interacting processes developing at different time scales (Fig. 1). As presented in Fig. 1, with technology advancement, the focus of daily maintenance of diabetes shifts from episodic physician encounters (slowest cycle) and lab assessments (e.g. A1c measured every few months) to daily fine tuning assisted by advisory systems or automated by the AP. Each person's behavior introduces routine (e.g. meals exercise) or abrupt (e.g. illness) perturbations. While the data at the slowest and fastest cycles are well defined (e.g. A1c and CGM), the tracking of behavioral perturbations is less common, even with contemporary applications that attempt to track human behavior. At this intermediate behavioral cycle, analytics are virtually absent; thus, the field is open for innovation and development.

The initialization of the ecosystem for a person begins with the diagnosis of diabetes, followed by choice of treatment (e.g. medication, technology) that is based on the person's physiology as reflected by the medical record and corresponds to education, skills, or social choices. This is done infrequently. A person's self- treatment routine (e.g. meals, exercise) is a dynamical process introducing daily behavioral perturbations to the metabolic system. These perturbations challenge the technological treatment of diabetes, which includes real-time warning, alarms, advisory systems, or automated insulin delivery. Thus, the key to optimal diabetes treatment is a multi-layer holistic approach, which must use advanced bioelectronics and technology to account for individual factors of human physiology and behavior. The optimization of diabetes must rely on an entire bio-behavioral treatment ecosystem of signals, models, and control methods that act at several levels of biosystem organization - from metabolic to human behavior and social interaction.

\section{A century of diabetes technology}

In the early 60's, an intravenous (i.v.) insulin pump delivering insulin and glucagon to counteract hypoglycemia was reported by Kadish (1964). In 1969, the first portable blood glucose meter - the Ames Reflectance meter - was manufactured. The first commercial subcutaneous insulin pump - the Auto Syringe - was introduced by Kamen in the 1970s, and by the end of the 70's the first trials of continuous subcutaneous insulin infusion (CSII) were reported by Pickup et al. in the U.K. (Pickup et al. 1978) and Tamborlane et al. in the U.S. (Tamborlane et al. 1979). These devices demonstrated the feasibility of ambulatory glucose measurement and external, including subcutaneous, insulin delivery. The next step was to automate the process of insulin replacement in type 1 diabetes - from BG monitoring to insulin delivery controlled by a mathematical algorithm. This approach became known as closed-loop control of diabetes, or the "artificial pancreas (AP)." The AP idea can be traced

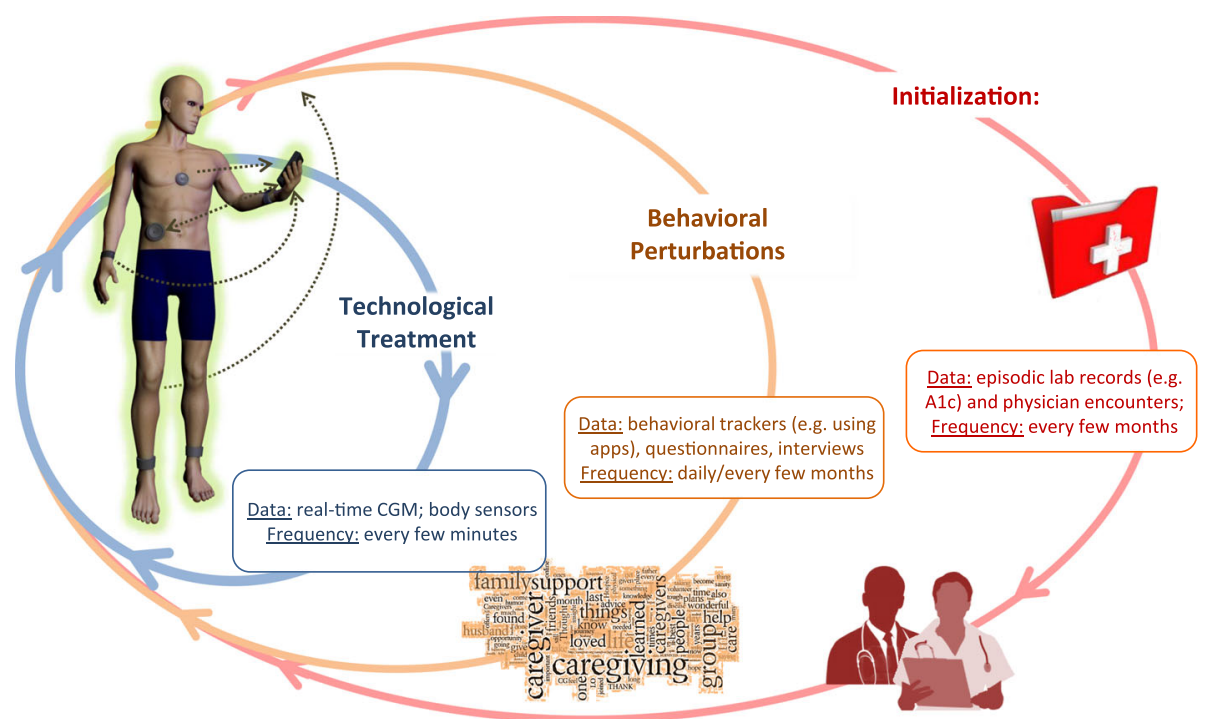

Fig. 1 The Treatment Ecosystem of diabetes - a combination of superimposed interacting processes developing at different time scales 
back to the 1970's when the possibility for external blood glucose regulation was established by studies using i.v. glucose measurement and i.v. infusion of glucose and insulin (Albisser et al. (1974), Pfeiffer et al. (1974), Mirouze et al. (1977), Kraegen et al. (1977), and Shichiri et al. (1978)). In 1977, one of these designs (Pfeiffer et al. 1974) resulted in the first commercial device - the Biostator (Clemens et al. 1977) - a large (refrigerator-sized) device that has been used extensively for glucose-control research (Marliss et al. 1977; Santiago et al. 1979; Fischer et al. 1978). A review of the methods for i.v. glucose control developed in the 70's can be found in (Parker et al. 2001). In 1979, another key element - the Minimal Model of Glucose Kinetics - was introduced by Bergman and Cobelli (Bergman et al. 1979). This, and subsequent mathematical models, serve as the "brain" behind the majority of control algorithms used in contemporary artificial pancreas systems. Detailed description of the major early algorithm designs can be found in (Broekhuyse et al. 1981; Clemens 1979; Cobelli and Ruggeri 1983; Salzsieder et al. 1985). More work followed, spanning a range of control techniques powered by physiologic modeling and computer simulation (Brunetti et al. 1993; Fischer et al. 1987; Sorensen 1985; Parker et al. 1999). Between 1980 and 2000 the insulin pumps became smaller and portable, while the models of the glucose-insulin system became larger and more elaborate, allowing first computer simulation and then automated model-predictive glucose control of diabetes. In 1997-1998, the first elements of the risk analysis of BG data were introduced (Kovatchev et al. 1997; Kovatchev et al. 1998), which later became the base for closed-loop safety systems embedded in the AP design. Figure 2, which was first published in (Kovatchev 2018a), presents the timeline of these developments:

\section{Continuous glucose monitoring}

The final critical technological leap enabling minimallyinvasive closed-loop was made at the turn of the twenty-first century with the introduction of CGM devices by Medtronic, Abbott, Dexcom, Cygnus, and others (Mastrototaro 2000; Bode 2000; Feldman et al. 2003). It is important to know, however, that CGM devices measure glucose concentration in a different compartment - the interstitium - which introduces an additional (presumably diffusion) process between blood and interstitial glucose (IG) (Rebrin et al. 1999; Rebrin and Steil 2000; Steil et al. 2005). To account for the gradient between BG and IG, CGM devices are typically calibrated with capillary BG readings. Successful calibration would adjust the amplitude of IG fluctuations with respect to $B G$, but would only partially mitigate the time lag due to BG-to-IG glucose transport. Because such a time lag could greatly influence the accuracy of CGM, a number of studies were dedicated to its investigation (Boyne et al. 2003; Kulcu et al. 2003; Stout et al. 2004; Wentholt et al. 2004). It was hypothesized that if a glucose fall is due to peripheral glucose consumption, the physiologic time lag would be negative, i.e. fall in IG would precede fall in BG (Rebrin et al. 1999; Wientjes and Schoonen 2001). But, in most studies, IG lagged behind BG by $4-10 \mathrm{~min}$, regardless of the direction of BG change (Steil et al. 2005; Boyne et al. 2003). In an attempt to reconcile these results, the formulation of the push-pull phenomenon offered arguments for a more complex BG-IG relationship than a simple constant or directional time lag (Wentholt et al. 2004; Aussedat et al. 2000; Basu et al. 2013; Basu et al. 2015). In addition, errors from calibration, loss of sensitivity, and random noise confound CGM data (Kovatchev and Clarke 2008). Nevertheless, the accuracy of CGM is increasing (Clarke and Kovatchev 2007; The Diabetes Research in Children



Fig. 2 Timeline of diabetes technology development following the discovery of insulin in 1921 
Network (DirecNet) Study Group 2008; Kovatchev et al. 2008; Garg et al. 2009; Christiansen et al. 2013) and has reached a point where CGM could be used as a replacement to traditional BG measurement without calibration with capillary blood several times a day (Kovatchev et al. 2015). For example, a few years ago the Dexcom G4 Platinum and G5 CGMs used algorithmic signal processing to improve its accuracy and obtain replacement clearance from the Food and Drug Administration (FDA) (Facchinetti et al. 2013; Peyser et al. 2015; Kovatchev 2015). Most recently, the new version of these devices - Dexcom G6 - was approved by the FDA for use without fingerstick calibration.

\section{Closed-loop control}

In addition to presenting frequent data (e.g. every 5$10 \mathrm{~min}$ ), real-time CGM devices typically display trends, BG rate of change, and alerts for upcoming hypo- or hyperglycemia (Heise et al. 2003; Bode et al. 2004; McGarraugh and Bergenstal 2009). As a result, a number of studies have documented the benefits of CGM technology (Deiss et al. 2006; Garg et al. 2006; Kovatchev and Clarke 2007; The Juvenile Diabetes Research Foundation Continuous Glucose Monitoring Study Group 2008) and envisioned its use in closed-loop control systems (Klonoff 2005; Hovorka 2006; Klonoff 2007). The first step in this direction was the introduction of a system attempting to prevent hypoglycemia via automated shutoff of the insulin pump when CGM readings crossed a predetermined low glucose threshold (Buckingham et al. 2009) - a feature that became known as Low Glucose Suspend (LGS) - or Predictive Low Glucose Suspend (PLGS) in implementations which used forecast of glucose values. First steps towards fully automateing the glucose control in diabetes using CGM and CSII linked via a closed-loop control algorithm, were taken by the early work of Hovorka et al. (2004a) and Steil et al. (2006). The launch of the JDRF AP Consortium in 2006, which sponsored several centers in the U.S. and Europe to carry closed-loop control research, institutionalized this trend. In 2009 JAMA wrote: "Artificial pancreas may soon be a reality" (Friedrich 2009). In May 2012, a Diabetes Outlook was published in Nature (Dolgin 2012) which highlighted the AP, and 18 months later Science featured the same topic (Clery 2014). In 2008 the National Institutes of Health (NIH) launched an AP initiative and in 2010 the European AP@Home Consortium was established. A roadmap towards a viable AP was accepted, which included several sequential steps, beginning with automated mitigation of hypoglycemia and progressing through control-to-range and controlto-target towards fully automated, possibly multi-hormonal AP (Kowalski 2009). By 2010 the AP became a global research topic engaging physicians and engineers in an unprecedented collaboration. In 2014, JAMA revisited the AP and suggested: "Fully automated artificial pancreas finally within reach" (Hampton 2014). Key milestones of this development are described in our reviews (Cobelli et al. 2011; Kovatchev 2011; Renard et al. 2013a; Renard et al. 2013b).

\section{The control algorithm}

A key element of the AP system is the control algorithm, which monitors BG fluctuations and the actions of the insulin pump, and computes insulin delivery rate every few minutes (Bellazzi et al. 2001). The first studies of Hovorka et al. (2004a; 2004b) and Steil et al. (2006) outlined the two major types of closed-loop control algorithms now in use - model-predictive control (MPC, (Hovorka et al. 2004b)) and proportional-integral-derivative (PID, (Steil et al. 2006)). By 2007, the blueprints of the contemporary controllers were in place, including run-to-run control (Zisser et al. 2005; Owens et al. 2006; Palerm et al. 2007) and linear MPC (Magni et al. 2007). MPC became the approach of choice targeted by recent research, for two main reasons: (i) PID is purely reactive, responding to changes in glucose level, while a properly tuned MPC allows for prediction of glucose dynamics and, as a result, for mitigation of the time delays inherent with subcutaneous glucose monitoring and subcutaneous insulin infusion; (ii) MPC allows for relatively straightforward personalizing of the control using patient-specific model parameters. In addition, MPC could have "learning" capabilities - it has been shown that a class of algorithms (known as runto-run control) can "learn" specifics of patients' daily routine and then optimize the response using this information. A combination of MPC and PID was used to drive a dual-hormone AP system that added glucagon to combat hypoglycemia (El-Khatib et al. 2010a). A new step towards adaptive AP was recently taken by a12-week multi-center trial of 24/7 personalized closed-loop control (Dassau et al. 2017). In this trial, each participant's insulin requirements (e.g. basal rate settings, carbohydrate ratio) were algorithmically adapted every week.

\section{Inpatient AP studies}

During 2008-2012, promising results were reported by several groups (Weinzimer et al. 2008; Clarke et al. 2009; Bruttomesso et al. 2009; Hovorka et al. 2010; El-Khatib et al. 2010b; Renard et al. 2010; Hovorka et al. 2011; Zisser et al. 2011; Russell et al. 2012; Breton et al. 2012; Luijf et al. 2013; Zisser et al. 2014; Sherr et al. 2013). Most of these studies pointed out the superiority of closed-loop control over CSII therapy in terms of: (i) increased time within target range (typically $70-180 \mathrm{mg} /$ dl); (ii) reduced incidence of hypoglycemia, and (iii) better overnight control. Inpatient studies linked AP to reduction of hypoglycemia following exercise (Breton et al. 2012; Zisser et al. 2014; Sherr et al. 2013), and an 
auxiliary heart rate signal was shown to contribute to better AP adaptation to exercise (Breton et al. 2014). An algorithm mimicking $\beta$-cell physiology was embedded in a low-power microchip (Reddy et al. 2014), and an MPC control algorithm running on a smart phone was tested in the hospital (O'Grady et al. 2012). A direct comparison between single- vs. dual-hormone AP found "little evidence of glucagon benefits in reducing the number of hypoglycemic events requiring treatment" (Haidar et al. 2015) - an important finding that helped settle the debate whether dual-hormone AP using glucagon is justified, given the added complexity, possible risks, and expenses.

\section{AP system integration}

LGS, which is now commercially available and is already a part of the clinical practice, is considered a precursor to AP because of the automated data transfer from CGM to the insulin pump - a system integration that was a critical step in the AP development. The ASPIRE trial showed a $38 \%$ reduction in nocturnal hypoglycemia compared to CGM alone without increasing HbA1c (Bergenstal et al. 2013); a subsequent study achieved similar results (Ly et al. 2013). PLGS algorithms were introduced (Beck et al. 2014), which brought this type of system to a higher level of computational sophistication. However, LGS and PLGS systems are still binary on-off insulin "switches;" they lack the defining property of a closed-loop algorithm - feedback estimation of the patient state using CGM and insulin delivery data to determine the degree or insulin modulation in real time.

\section{Outpatient (but not portable) AP}

The first steps towards outpatient AP were taken by a laptop-based system installed at the bedside of children at a diabetes camp (Phillip et al. 2013), and then taken to patients' homes (Nimri et al. 2013). Similarly, another bedside AP trial deployed small personal computers at patients' homes, and confirmed their feasibility outside of the hospital (Hovorka et al. 2014). The progress of the outpatient AP was presented in a symposium "Advances in Artificial Pancreas Development" (Diabetes Care, May 2014), which contained an editorial (Cefalu and Tamborlane 2014) and 7 papers on topics ranging from physiology and engineering (Kudva et al. 2014; Schiavon et al. 2014) to reports on predictive LGS (Beck et al. 2014), overnight AP at home (Hovorka et al. 2014), feasibility of the AP in type 2 diabetes (Kumareswaran et al. 2014), and around-the-clock outpatient AP with a portable AP system (Del Favero et al. 2014). Subsequent studies firmly took the AP to outpatient setting (Russell et al. 2014; Leelarathna et al. 2014; Thabit et al. 2014).

\section{Wearable artificial pancreas}

In the Nature (Dolgin 2012) and Science (Clery 2014) reviews cited above, a common photo appeared of a smart phone presenting a dual traffic-light display - the face of the first portable AP platform-the Diabetes Assistant (DiAs) developed at the University of Virginia (UVA) in 2011. DiAs was built using an Android smart phone as a computational hub and, for the first time, included two features now employed by virtually all outpatient AP systems: (i) graphical user interface designed for the patient (Keith-Hynes et al. 2013), and (ii) a Web-based remote monitoring system (Place et al. 2013). The defining characteristic of DiAs was its capability to switch between different modes of operation, depending on patient preference and signal availability. For example, if CGM signal were not available or if the patient does not wear a sensor for a certain period of time, DiAs could switch into "pump mode" running this patient's normal basal/ bolus insulin routine and adding extended GUI and remote monitoring. Similarly, if the pump were unavailable, DiAs could switch to "sensor mode" running trends, alerts, and Cloud services. Thus, by design, DiAs was a platform for AP technology deployment, used in 20 clinical trials, by over 300 patients at clinical centers in the U.S. (Virginia, California, Minnesota, and New York), as well as in France, Italy, Holland, Israel, and Argentina. Some examples: Following initial 2-day pilot-feasibility trials (Cobelli et al. 2012), in 2012-2013 two international multi-site studies were completed, which confirmed the feasibility of DiAs and its efficacy to reduce hypoglycemia in the outpatient setting (Kovatchev et al. 2013; Kovatchev et al. 2014). Three summer camp trials of remote monitoring (DeSalvo et al. 2013), overnight AP (Ly et al. 2014), and AP during the day (Chernavvsky et al. 2016) confirmed the efficacy of DiAs in children with type 1 diabetes. With several completed multi-center trials, smart-phone based closed-loop control is now considered an established and effective approach to portable AP (Brown et al. 2015a; Del Favero et al. 2015; Brown et al. 2015b; Anderson et al. 2015; Renard et al. 2015).

The studies done in the past few years ascertained the two principal implementations of a wearable AP - a system embedded in the insulin pump and a mobile system based on a smart phone. These system configurations are presented in Fig. 3, which was first published in $\mathrm{Na}$ ture Reviews Endocrinology in a visually different, but conceptually similar form (Kovatchev 2018b).

Each of the configurations presented in Fig. 3 has advantages and disadvantages, and both are likely to coexist as means for automated insulin delivery. Embedded systems have fewer components and fewer wireless connections and, theoretically, should be more reliable that a consumer electronics device such as a smart phone. However: (i) smart phones are inexpensive, available, 

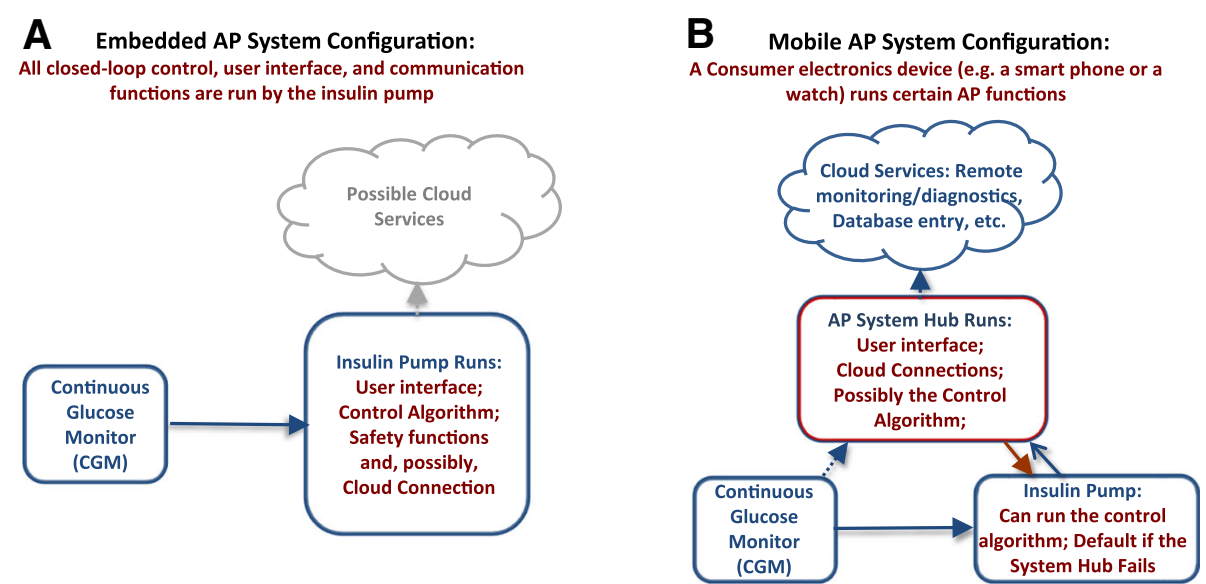

Fig. 3 The two principal configurations of a wearable artificial pancreas: embedded, with a control algorithm running on board of an insulin pump, and mobile, using consumer electronics as a computational and communication hub. Both configurations have their advantages and disadvantages

computationally able to run even complicated control algorithms, and wirelessly connectable to various devices and data networks-no current insulin pump offers similar capabilities; (ii) the life cycle of a smart phone is months, as opposed to years for insulin pumps; thus, smart phones allow easier updates of user interface and device form factor; (iii) psychologists share that patients, particularly youth, miss boluses because of reluctance to use their insulin pump in public; but, no one is reluctant to use a phone and that may be a key to AP success and widespread adoption. Thus, the last remaining question is whether an AP system based on consumer electronics could receive regulatory clearance from the FDA, and this subject is intensively discussed now.

The progress of the artificial pancreas was presented in a symposium published by Diabetes Care in July 2016 (Kovatchev et al. 2016), which was exclusively dedicated to outpatient closed-loop control studies done with portable AP systems (Anderson et al. 2016; Renard et al. 2016; Tauschmann et al. 2016; Del Favero et al. 2016), including trials at patient's homes lasting a month or more (Anderson et al. 2016; Renard et al. 2016; Tauschmann et al. 2016) and studies in young children (Del Favero et al. 2016). Recently, I summarized the progress made in 2017 - the year of transition of the AP to everyday clinical use (Kovatchev 2018b) - as follows:

(1) A pivotal trial of the first commercial hybrid CLC system was completed - the Medtronic 670G which modulates automatically basal rate but does not automate insulin boluses. Following the initial summary published in JAMA (Bergenstal et al. 2016), Garg et al. (2017) reported detailed glycemic control outcomes from the use of this system in adolescents (ages 14-21 years) and adults. This study allowed the comprehensive testing the safety of in-home use of hybrid CLC and the subsequent regulatory approval of the system by the U.S. Food and Drug Administration (FDA), thereby opening the AP field to routine clinical use;

(2) A six-month pilot-feasibility study of long-term closed-loop control was reported showing improvements in glycemic control and simultaneous reduction of hypoglycemia with long-term AP use (Kovatchev et al. 2017);

(3) Long-term (up to 10 months) studies were initiated using a successor of the DiAs system - inControl AP (TypeZero Technologies), which runs on android smart phone and connects wirelessly to a CGM sensor and an insulin pump;

(4) The National Institutes of Health invested over $\$ 35 \mathrm{M}$ in four pivotal trials of closed-loop control technologies intended to bring these systems to market - a press release can be found at https:// www.nih.gov/news-events/news-releases/four-pivotalnih-funded-artificial-pancreas-research-efforts-begin,, and

(5) The first AP Ski Camp and was successfully completed indicating that the use of closed-loop control in the conditions of winter sports ( $5 \mathrm{~h}$ of skiing per day for 5 days) is safe and effective for children and adolescents with type 1 diabetes (Breton et al. 2017).

\section{Conclusions}

The Artificial Pancreas technology is indeed within reach, and is the ultimate bioelectronics approach to improve glucose control in diabetes. In the process of AP development, new technologies were developed, together 
with sophisticated models of the human metabolic system. Continuous glucose monitoring and insulin pumps are now mainstream. The 2008 FDA acceptance of the UVA/ University of Padova computer simulator as a substitute to animal trials in the design and safety pre-clinical testing of AP controllers opened the field for rapid and cost-effective in silico experiments (Kovatchev et al. 2009a). Since then, no animal experiments have been conducted for the purpose of designing AP algorithms. It can be envisioned that virtual environments will increasingly allow thorough testing of myriad control cycles in extreme physiological situations, or during low-probability system failures, that cannot be reproduced in real life (Viceconti et al. 2017). Modular architecture allows AP systems to be assembled from independent (but compatible) modules, each performing a specific function, e.g. prevention of hypoglycemia, post-meal insulin corrections, fine tuning of basal rate, or administration of ancillary compounds such as amylin or glucagon (Kovatchev et al. 2009b). Modularity is essential for the "graceful degradation" of the system in the event of component failure and permits critical functions to be redundant, residing in more than one module, and redirected to avoid system meltdown (Patek et al. 2012).

Two main AP system configurations have emerged: embedded, running a control algorithm in the insulin pump and mobile, using a smart phone as a data processing and communication device. Traditionally, it was assumed that the AP control system would reside in a patient's insulin pump, which is the case with most commercial developments. An alternative solution was suggested by DiAs, which was based on appropriately configured consumer electronic devices (smart phone). This approach offered certain advantages to the initial research phase of AP development, and may be potentially viable for commercial systems as well.

In conclusion, to be ultimately established and accepted as a viable treatment of diabetes, AP systems need to prove their safety and efficacy in large-scale clinical trials with outcomes tied to the key components of glycemic control in diabetes - hemoglobin A1c and risk for hypoglycemia. These validations are ongoing now; thus, the optimism is high for the closed-loop artificial pancreas becoming soon the digital-age bioelectronics approach to the treatment of diabetes.

\section{Abbreviations}

ADA: American Diabetes Association; AP: Artificial Pancreas; BG: Blood Glucose; CGM: Continuous Glucose Monitoring; CSII: Continuous Subcutaneous Insulin Infusion; DiAs: Diabetes Assistant; EASD: European Association for the Study of Diabetes; FDA: Food and Drug Administration; GIP: Glucose-dependent Insulinotropic Peptide; GLP-1: Glucagon-like Peptide-1; IDDM: Insulin-Dependent Diabetes Mellitus; IDF: International Diabetes Federation; IFG: Impaired Fasting Glucose; IG: Interstitial Glucose; IGT: Impaired Glucose Tolerance; LGS: Low Glucose Suspend; MDI: Multiple Daily Injections; MPC: Model-Predictive Control; $\mathrm{NIH}$ : National Institutes of Health; PID: Proportional-Integral-Derivative; PLGS: Predictive Low Glucose Suspend; UVA: University of Virginia
}

Funding

The University of Virginia's Precision Individualized Medicine for Diabetes (PrIMeD) Project supported in part the writing of this review.

\section{Authors' contributions}

BK wrote this review. The author read and approved the final manuscript.

Ethics approval and consent to participate

Not Applicable.

\section{Consent for publication \\ Not Applicable.}

\section{Competing interests}

The author reports patents and patent applications related to diabetes technology managed by the University of Virginia Licensing and Ventures group; Research support managed by the University of Virginia from: Dexcom, Roche Diagnostics, Tandem Diabetes Care; Speaking Engagement/ Advisory panel/Consultant: Dexcom, Sanofi Aventis; Formerly: Board member and shareholder, TypeZero Technologies.

\section{Publisher's Note}

Springer Nature remains neutral with regard to jurisdictional claims in published maps and institutional affiliations.

Received: 27 August 2018 Accepted: 8 October 2018

Published online: 07 November 2018

\section{References}

Albisser AM, Leibel BS, Ewart TG, Davidovac Z, Botz CK, Zingg W. An artificial endocrine pancreas. Diabetes. 1974;23:389-96.

American Diabetes Association. Economic costs of Diabetes in the U.S. in 2012. Diabetes Care. 2013;36:1033-46.

American Diabetes Association [Internet]. Alexandria (VA): c1995-2015. (n.d.) Available from: http://www.diabetes.org.

Amiel SA, Sherwin RS, Simonson DC, Tamborlane W. Effect of intensive insulin therapy on glycemic thresholds for counterregulatory hormone release. Diabetes. 1988:37:901-7. 3290007.

Amiel SA, Tamborlane WV, Simonson DC, Sherwin RS. Defective glucose counterregulation after strict glycemic control of insulin-dependent diabetes mellitus. N Engl J Med. 1987;316:1376-83. 3553949.

Anderson S, et al. First new year's night on closed-loop control (CLC) at home: Case reports from a multi-center international trial of long-term 24/7 CLC. American Diabetes Association 75 ${ }^{\text {th }}$ Scientific Sessions; 2015. p. 4763.

Anderson SM, Raghinaru D, Pinsker JE, Boscari F, Renard E, Buckingham BA, Nimri R, Doyle FJ 3rd, Brown SA, Keith-Hynes P, Breton MD, Chernavvsky D, Bevier WC, Bradley PK, Bruttomesso D, Del Favero S, Calore R, Cobelli C, Avogaro A, Farret A, Place J, Ly TT, Shanmugham S, Phillip M, Dassau E, Dasanayake IS, Kollman C, Lum JW, Beck RW, Kovatchev BP. Multinational home use of closed-loop control is safe and effective. Diabetes Care. 2016;39:1143-50.

Aussedat B, Dupire-Angel M, Gifford R, Klein JC, Wilson GS, Reach G. Interstitial glucose concentration and glycemia: implications for continuous subcutaneous glucose monitoring. Am J Physiol Endocrinol Metab. 2000; 278:E716-28.

Basu A, Dube S, Slama M, Errazuriz I, Amezcua JC, Kudva YC, Peyser T, Carter RE, Cobelli C, Basu R. Time lag of glucose from intravascular to interstitial compartment in humans. Diabetes. 2013;62:4083-7.

Basu A, Dube S, Veettil S, Slama M, Kudva YC, Peyser T, Carter RE, Cobelli C, Basu R. Time lag of glucose from intravascular to interstitial compartment in type 1 diabetes. J Diabetes Sci Technol. 2015;9(1):63-68.

Beck RW, Raghinaru D, Wadwa RP, Chase HP, Maahs DM, Buckingham BA. For the in home closed loop study group. Frequency of morning ketosis after overnight insulin suspension using an automated nocturnal predictive low glucose suspend system. Diabetes Care. 2014;37:1224-9.

Bellazzi R, Nucci G, Cobelli C. The subcutaneous route to insulin-dependent diabetes therapy: closed-loop and partially closed-loop control strategies for insulin delivery and measuring glucose concentration. IEEE Eng Med Biol. 2001;20:54-64.

Bergenstal RM, Klonoff DC, Garg SK, Bode BW, Meredith M, Slover RH, Ahmann AJ, Welsh JB, Lee SW, Kaufman FR, for the ASPIRE in-home study group. 
Threshold-based insulin-pump interruption for reduction of hypoglycemia. N Engl J Med. 2013;369:224-32.

Bergenstal RM, et al. Safety of a hybrid closed-loop insulin delivery system in patients with type 1 diabetes. JAMA Published online September 15. 2016; 316(13):1407-8.

Bergman RN, Ider YZ, Bowden CR, Cobelli C. Quantitative estimation of insulin sensitivity. Am J Phys. 1979;236:E667-77.

Bode B, Gross K, Rikalo N, Schwartz S, Wahl T, Page C, Gross T, Mastrototaro J. Alarms based on real-time sensor glucose values alert patients to hypo- and hyperglycemia: the Guardian continuous monitoring system. Diabetes Technol Ther. 2004;6:105-13.

Bode BW. Clinical utility of the Continuous Glucose Monitoring System. Diabetes Technol Ther. 2000;2(Sup 1):S-35-42.

Boyne M, Silver D, Kaplan J, Saudek C. Timing of changes in interstitial and venous blood glucose measured with a continuous subcutaneous glucose sensor. Diabetes. 2003;52:2790-4.

Breton MD, Brown SA, Karvetski CH, Kollar L, Topchyan KA, Anderson SM, Kovatchev BP. Adding heart rate signal to a control-to-range artificial pancreas system improves the protection against hypoglycemia during exercise in type 1 diabetes. Diabetes Technol Ther. 2014;16:506-11.

Breton MD, Cherñavvsky DR, Forlenza GP, DeBoer MD, Robic J, Wadwa RP, Messer LH, Kovatchev BP, Maahs DM. Closed Loop Control During Intense Prolonged Outdoor Exercise in Adolescents With Type 1 Diabetes: The Artificial Pancreas Ski Study. Diabetes Care. 2017:40(12):1644-50 https://doi. org/10.2337/dc17-0883.

Breton MD, Farret A, Bruttomesso D, Anderson SM, Magni L, Patek S, Dalla Man C, Place J, Demartini S, Del Favero S, Toffanin C, Karvetski CH, Dassau E, Zisser H, Doyle FJ 3rd, De Nicolao G, Avogaro A, Cobelli C, Renard E, Kovatchev BP, on behalf of The International Artificial Pancreas (iAP) Study Group. Fully-integrated artificial pancreas in Type 1 Diabetes: Modular closed-loop glucose control maintains near-normoglycemia. Diabetes. 2012:61:2230-7.

Broekhuyse HM, Nelson JD, Zinman B, Albisser AM. Comparison of algorithms for the closed-loop control of blood glucose using the artificial beta cell. IEEE Trans Biomed Eng. 1981;28:678-87.

Brown S, et al. Artificial pancreas improves glycemic control in a multi-night multicenter outpatient/home study of patients with T1D. ADA $75^{\text {th }}$ Scientific Sessions; 2015b. p. 4197.

Brown SA, Kovatchev BP, Breton MD, Anderson SM, Keith-Hynes P, Patek SD, Jiang B, Ben Brahim N, Vereshchetin P, Bruttomesso D, Avogaro A, Del Favero S, Boscari F, Galasso S, Visentin R, Monaro M, Cobelli C. Multinight "bedside" closed-loop control for patients with Type 1 Diabetes. Diabetes Technol Ther. 2015a;17(3):203-9. https://doi.org/10.1089/dia.2014.0259.

Brunetti P, Cobelli C, Cruciani P, Fabietti PG, Filippucci F, Santeusanio F. A simulation study on a self-tuning portable controller of blood glucose. Int J Artificial Organs. 1993;16:51-7.

Bruttomesso D, Farret A, Costa S, Marescotti MC, Vettore M, Avogaro A, Tiengo A, Dalla Man C, Place J, Facchinetti A, Guerra S, Magni L, De Nicolao G, Cobelli C, Renard E, Maran A. Closed-loop artificial pancreas using subcutaneous glucose sensing \& insulin delivery, and a model predictive control algorithm: preliminary studies in Padova and Montpellier. J Diabetes Sci Technol. 2009:3:1014-21.

Buckingham B, Cobry E, Clinton P, Gage V, Caswell K, Kunselman E, Cameron F, Chase HP. Preventing hypoglycemia using predictive alarm algorithms and insulin pump suspension. Diabetes Technol Ther. 2009;11:93-7.

Cefalu WT, Tamborlane WV. The artificial pancreas: are we there yet? Diabetes Care. 2014:37:1182-3.

Chernavvsky DR, DeBoer MD, Keith-Hynes P, Mize B, McElwee M, Demartini S, Dunsmore SF, Wakeman C, Kovatchev BP, Breton MD. Use of an artificial pancreas among adolescents for a missed snack bolus and an underestimated meal bolus. Pediatr Diabetes. 2016;17(1):28-35.

Christiansen M, Bailey T, Watkins E, Liljenquist D, Price D, Nakamura K, Boock R, Peyser T. A new-generation continuous glucose monitoring system: improved accuracy and reliability compared with a previous-generation system. Diabetes Technol Ther. 2013;15:881-8.

Clarke WL, Anderson SM, Breton MD, Patek SD, Kashmer L, Kovatchev BP. Closedloop artificial pancreas using subcutaneous glucose sensing and insulin delivery and a model predictive control algorithm: the Virginia experience. J Diabetes Sci Technol. 2009:3:1031-8,

Clarke WL, Kovatchev BP. Continuous glucose sensors - continuing questions about clinical accuracy. J Diabetes Sci Technol. 2007;1:164-70.
Clemens AH. Feedback control dynamics for glucose controlled insulin infusion system. MedProg Technol. 1979;6:91-8.

Clemens AH, Chang PH, Myers RW. The development of biostator, a glucosecontrolled insulin infusion system (GCIIS). Horm Metab Res Supplement. 1977:23-33.

Clery D. A pancreas in a box. Science. 2014:343:133-15.

Cobelli C, Dalla Man C, Sparacino G, Magni L, De Nicolao G, Kovatchev BP. Diabetes: models, signals, and control. IEEE Rev Biomed Eng. 2009;2: 54-96.

Cobelli C, Renard E, Kovatchev BP. Artificial pancreas: past, present, future. Diabetes. 2011;60:2672-82.

Cobelli C, Renard E, Kovatchev BP, Keith-Hynes P, Ben Brahim N, Place J, Del Favero S, Breton MD, Farret A, Bruttomesso D, Dassau E, Zisser H, Doyle FJ III, Patek S, Avogaro A. Pilot studies of wearable artificial pancreas in type 1 diabetes. Diabetes Care. 2012;35:e65-7.

Cobelli C, Ruggeri A. Evaluation of portal/peripheral route and of algorithms for insulin delivery in the closed-loop control of glucose in diabetes. A modeling study. IEEE Trans Biomed Eng. 1983;30:93-103.

Cryer PE. Hypoglycemia: the limiting factor in the management of IDDM. Diabetes. 1994;43:1378-89. 7926315.

Cryer PE. Glycemic goals in diabetes: trade-off between glycemic control and iatrogenic hypoglycemia. Diabetes. 2014;63:2188-95. 24962915.

Cryer PE, Davis SN, Shamoon H. Hypoglycemia in diabetes. Diabetes Care. 2003; 26:1902-12. 12766131.

Cryer PE, Gerich JE. Glucose counterregulation, hypoglycemia, and intensive therapy of diabetes mellitus. N Engl J Med. 1985;313:232-41.

Dassau E. et al. 12-week 24/7 ambulatory artificial pancreas with weekly adaptation of insulin delivery settings: effect on hemoglobin A1c and hypoglycemia. Diabetes Care doi: https://doi.org/10.2337/dc17-1188. [Epub ahead of print] (2017).

Deiss D, Bolinder J, Riveline J, Battelino T, Bosi E, Tubiana-Rufi N, Kerr D, Phillip M. Improved glycemic control in poorly controlled patients with type 1 diabetes using real-time continuous glucose monitoring. Diabetes Care. 2006:29:2730-2.

Del Favero S, Boscari F, Messori M, Rabbone I, Bonfanti R, Sabbion A, laFusco D, Schiaffini R, Visentin R, Calore R, Moncada YL, Galasso S, Galderisi A, Vallone V, Di Palma F, Losiouk E, Lanzola G, Tinti D, Rigamonti A, Marigliano M, Zanfardino A, Rapini N, Avogaro A, Chernavvsky D, Magni L, Cobelli C, Bruttomesso D. Randomized Summer Camp Crossover Trial in 5- to 9-YearOld Children: Outpatient Wearable Artificial Pancreas Is Feasible and Safe. Diabetes Care. 2016:39:1180-5. 27208335.

Del Favero S, Bruttomesso D, Di Palma F, Lanzola G, Visentin R, Filippi A, Scotton R, Toffanin C, Messori M, Scarpellini S, Hynes PK, Kovatchev BP, DeVries JH, Renard E, Magni L, Avogaro A, Cobelli C on behalf of the AP@home Consortium. First use of model predictive control in outpatient wearable artificial pancreas. Diabetes Care. 2014;37:1212-5.

Del Favero S, Place J, Kropff J, Messori M, Keith-Hynes P, Visentin R, Monaro M, Galasso S, Boscari F, Toffanin C, Di Palma F, Lanzola G, Scarpellini S, Farret A, Kovatchev BP, Avogaro A, Bruttomesso D, Magni L, JH DV, Cobelli C, Renard E, on behalf of AP@home. Multicenter outpatient dinner/overnight reduction of hypoglycemia and increased time of glucose in target with a wearable artificial pancreas using modular model predictive control in adults with Type 1 Diabetes. Diabetes Obes Metabolism. 2015;17:468-76.

DeSalvo D, Keith-Hynes P, Peyser T, Place J, Caswell K, Wilson D, Harris B, Clinton $P$, Kovatchev BP, Buckingham BA. Remote glucose monitoring in camp setting reduces the risk of prolonged nocturnal hypoglycemia. Diabetes Technol Ther. 2013;16(1):1-7. https://doi.org/10.1089/dia.2013.0139.

Diabetes Technology. Burlingame (CA). (n.d.) Available from: http://www. diabetestechnology.org

Dolgin E. Managed by machine. Nature. 2012;485:56-8.

Drucker DJ, Nauck MA. The incretin system: glucagon-like peptide-1 receptor agonists and dipeptidyl peptidase-4 inhibitors in type 2 diabetes. Lancet. 2006;368:1696-705.

El-Khatib FH, Russell SJ, Nathan DM, Sutherlin RG, Damiano ER. A bihormonal closed-loop artificial pancreas for Type 1 Diabetes. Science Transl. Med. 2010a;2:27ra27.

El-Khatib FH, Russell SJ, Nathan DM, Sutherlin RG, Damiano ER. A bihormonal closed-loop artificial pancreas for type 1 diabetes. Science Transl med 2010;2: 27ra27. Atlas E, Nimri R, miller S, Grunberg EA, Phillip M. MD-logic artificial pancreas system: a pilot study in adults with type 1 diabetes. Diabetes Care. 2010b;33:1072-6. 
European Association for the Study of Diabetes [Internet]. Dusseldorf (Germany). (n.d.) Available from: http://www.easd.org.

Facchinetti A, Sparacino G, Guerra S, et al. Real-time improvement of continuous glucose monitoring accuracy: the smart sensor concept. Diabetes Care. 2013; 36:793-800.

Feldman B, Brazg R, Schwartz S, Weinstein R. A continuous glucose sensor based on wired enzyme technology - results from a 3-day trial in patients with type 1 diabetes. Diabetes Technol Ther. 2003;5:769-78.

Fischer U, Jutzi E, Freyse E-J, Salzsieder E. Derivation and experimental proof of a new algorithm for the artificial beta-cell based on the individual analysis of the physiological insulin- glucose relationship. Endokrinologie. 1978;71:65-75.

Fischer U, Schenk W, Salzsieder E, Albrecht G, Abel P, Freyse E-J. Does physiological blood glucose control require an adaptive strategy? IEEE Trans Biomed Eng. 1987;34:575-82.

Friedrich MJ. Artificial pancreas may soon be a reality. JAMA. 2009;301:1525-7.

Garg K, Zisser H, Schwartz S, Bailey T, Kaplan R, Ellis S, Jovanovic L. Improvement in glycemic excursions with a transcutaneous, real-time continuous glucose sensor. Diabetes Care. 2006;29:44-50.

Garg SK, et al. Glucose outcomes with the in-home use of a hybrid closed-loop insulin delivery system in adolescents and adults with type 1 diabetes. Diabetes Technol Ther. 2017;19:155-63.

Garg SK, Smith J, Beatson C, Lopez-Baca B, Voelmle M, Gottlieb PA. Comparison of accuracy and safety of the SEVEN and the navigator continuous glucose monitoring systems. Diabetes Tech Ther. 2009;11:65-72.

Gold AE, Deary IJ, Frier BM. Recurrent severe hypoglycaemia and cognitive function in type I diabetes. Diabet Med. 1993;10:503-8. 8365084.

Haidar A, Legault L, Messier V, Mitre TM, Leroux C, Rabasa-Lhoret R. Comparison of dual-hormone artificial pancreas, single hormone artificial pancreas, and conventional insulin pump therapy for glycaemic control in patients with type 1 diabetes: an open-label randomised controlled crossover trial. Lancet Diabetes Endocrinol. 2015;3:17-26.

Hampton T. Fully automated artificial pancreas finally within reach. JAMA. 2014; 311:2260-1.

Heise T, Koschinsky T, Heinemann L, Lodwig V, Glucose Monitoring Study Group. Hypoglycemia warning signal and glucose sensors: requirements and concepts. Diabetes Technol Ther. 2003;5:563-71.

Henderson JN, Allen KV, Deary IJ, Frier BM. Hypoglycemia in insulin-treated type 2 diabetes: frequency, symptoms and impaired awareness. Diabet Med. 2003; 20:1016-21. 14632703.

Hovorka R. Continuous glucose monitoring and closed-loop systems. Diabet Med. 2006;23:1-12

Hovorka R, Allen JM, Elleri D, Chassin LJ, Harris J, Xing D, Kollman C, Hovorka T, Larsen AMF, Nodale M, De Palma A, Wilinska ME, Acerini CL, Dunger DB. Manual closed-loop insulin delivery in children and adolescents with type 1 diabetes: a phase 2 randomised crossover trial. Lancet. 2010;375:743-51.

Hovorka R, Canonico V, Chassin LJ, et al. Nonlinear model predictive control of glucose concentration in subjects with type 1 diabetes. Physiol Meas. 2004b; 25:905-20.

Hovorka R, Chassin LJ, Wilinska ME, Canonico V, Akwi JA, Federici MO, MassiBenedetti M, Hutzli I, Zaugg C, Kaufmann H, Both M, Vering T, Schaller HC, Schaupp L, Bodenlenz M, Pieber TR. Closing the loop: the ADICOL experience. Diabetes Technol Ther. 2004a;6:307-18.

Hovorka R, Elleri D, Thabit H, Allen JM, Leelarathna L, El-Khairi R, Kumareswaran K, Caldwell K, Calhoun P, Kollman C, Murphy HR, Acerini CL, Wilinska ME, Nodale M, Dunger DB. Overnight closed-loop insulin delivery in young people with type 1 diabetes: a free-living, randomized clinical trial. Diabetes Care. 2014;37:1204-11.

Hovorka R, Kumareswaran K, Harris J, Allen JM, Elleri D, Xing D, Kollman C, Nodale M, Murphy HR, Dunger DB, Amiel SA, Heller SR, Wilinska ME, Evans ML. Overnight closed loop insulin delivery in adults with type 1 diabetes: crossover randomised controlled studies. BMJ. 2011;342:d1855.

International Diabetes Federation. Brussels (Belgium). c2014 Available from: http://www.idf.org

Kadish AH. Automation control of blood sugar. A servomechanism for glucose monitoring and control. Am J Med Electron. 1964;39:82-6.

Keith-Hynes P, Guerlain S, Mize LB, Hughes-Karvetski C, Khan M, McElwee-Malloy M, Kovatchev BP. DiAs user Interface: a patient-centric interface for mobile artificial pancreas systems. J Diabetes Sci Technol. 2013;7:1416-26.

Klonoff DC. Continuous glucose monitoring: roadmap for $21^{\text {st }}$ century diabetes therapy. Diabetes Care. 2005;28:1231-9.
Klonoff DC. The artificial pancreas: how sweet engineering will solve bitter problems. J Diabetes Sci Technol. 2007;1:72-81.

Kovatchev BP. Closed loop control for type 1 diabetes [editorial]. Br Med J. 2011; 342:1-2.

Kovatchev BP. Hypoglycemia reduction and accuracy of continuous glucose monitoring. Diabetes Technol Ther. 2015;17:530-3. https://doi.org/10.1089/ dia.2015.0144.

Kovatchev BP. Diabetes technology: monitoring, analytics, and optimal control. Cold Spring Harb Perspect Med. 2018a. https://doi.org/10.1101/ cshperspect.a034389.

Kovatchev BP. The artificial pancreas in 2017: the year of transition from research to clinical practice. Nat Rev Endocrinol. 2018b;14:74-6. 29286043.

Kovatchev BP, Anderson SM, Heinemann L, Clarke WL. Comparison of the numerical and clinical accuracy of four continuous glucose monitors. Diabetes Care. 2008:31:1160-4.

Kovatchev BP, Breton MD, Dalla Man C, Cobelli C. In silico preclinical trials: a proof of concept in closed-loop control of type 1 diabetes. J Diabetes Sc Technol. 2009a;3:44-55.

Kovatchev BP, Cheng P, Anderson SM, Pinsker JE, Boscari F, Buckingham BA, Doyle FJ. III, Hood KK, Brown SA. Breton MD, Chernavvsky DR, Bevier WC, Bradley PK, Bruttomesso D, Del Favero S, Calore R, Cobelli C, Avogaro A, Ly TT, Shanmugham S, Dassau E, Kollman C, Lum JW, Beck RW, for the control to range study group. Diabetes Technol Ther 2017; 19: 18-24. doi:https://doi. org/10.1089/dia.2016.0333.

Kovatchev BP, Clarke WL. Continuous glucose monitoring reduces risks for hypo- and hyperglycemia and glucose variability in diabetes. Diabetes. 2007:56(Suppl 1):00860R.

Kovatchev BP, Clarke WL. Peculiarities of the continuous glucose monitoring data stream and their impact on developing closed-loop control technology. J Diabetes Sci Technol. 2008:2:158-63.

Kovatchev BP, Cox DJ, Gonder-Frederick LA, Clarke WL. Symmetrization of the blood glucose measurement scale and its applications. Diabetes Care. 1997; 20:1655-8.

Kovatchev BP, Cox DJ, Gonder-Frederick LA, Young-Hyman D, Schlundt D, Clarke WL. Assessment of risk for severe hypoglycemia among adults with IDDM: validation of the low blood glucose index. Diabetes Care. 1998;21:1870-5.

Kovatchev BP, Patek SD, Dassau E, Doyle FJ III, Magni L, De Nicolao G, Cobelli C. Control-to-range for diabetes: functionality and modular architecture. J Diabetes Sci Technol. 2009b;3:1058-65.

Kovatchev BP, Patek SD, Ortiz EA, et al. Assessing sensor accuracy for nonadjunct use of continuous glucose monitoring. Diabetes Technol Ther. 2015;17:177-86

Kovatchev BP, Renard E, Cobelli C, Zisser H, Keith-Hynes P, Anderson SM, Brown $S A$, Chernavvsky DR, Breton MD, Farret A, Pelletier MJ, Place J, Bruttomesso D, Del Favero S, Visentin R, Filippi A, Scotton R, Avogaro A, Doyle FJ III. Feasibility of outpatient fully integrated closed-loop control: first studies of wearable artificial pancreas. Diabetes Care. 2013;36:1851-8.

Kovatchev BP, Renard E, Cobelli C, Zisser H, Keith-Hynes P, Anderson SM, Brown SA, Chernavvsky DR, Breton MD, Mize LB, Farret A, Place J, Bruttomesso D, Del Favero S, Boscari F, Galasso S, Avogaro A, Magni L, Di Palma F, Toffanin C, Messori M, Dassay E, Doyle F III. Safety of outpatient closed-loop control: first randomized crossover trials of a wearable artificial pancreas. Diabetes Care. 2014;37:1789-96.

Kovatchev BP, Tamborlane WV, Cefalu WT, Cobelli C. The artificial pancreas in 2016: a digital treatment ecosystem for diabetes. Diabetes Care. 2016; 39:1123-7.

Kowalski AJ. Can we really close the loop and how soon? Accelerating the availability of an artificial pancreas: a roadmap to better diabetes outcomes. Diabetes Technol Ther. 2009;11:S113-9.

Kraegen EW, Campbell LV, Chia YO, Meler H, Lazarus L. Control of blood glucose in diabetics using an artificial pancreas. Aust NZ J Med. 1977;7:280-6.

Kudva YC, Carter RE, Cobelli C, Basu R, Basu A. Closed-loop artificial pancreas systems: physiological input to enhance next-generation devices. Diabetes Care. 2014:37:1184-90.

Kulcu E, Tamada JA, Reach G, Potts RO, Lesho MJ. Physiological differences between interstitial glucose and blood glucose measured in human subjects. Diabetes Care. 2003;26:2405-9.

Kumareswaran K, Thabit H, Leelarathna L, Caldwell K, Elleri D, Allen JM, Nodale M, Wilinska ME, Evans ML, Hovorka R. Feasibility of closed-loop insulin delivery in type 2 diabetes: a randomized controlled study. Diabetes Care. 2014;37: $1198-203$. 
Leelarathna L, Dellweg S, Mader JK, Allen JM, Benesch C, Doll W, Ellmerer M, Hartnell S, Heinemann L, Kojzar H, Michalewski L, Nodale M, Thabit H, Wilinska ME, Pieber TR, Arnolds S, Evans ML, Hovorka R, AP@home Consortium. Day and night home closed-loop insulin delivery in adults with type 1 diabetes: three-center randomized crossover study. Diabetes Care. 2014:37:1931-7.

Lincoln NB, Faleiro RM, Kelly C, Kirk BA, Jeffcoate WJ. Effect of long-term glycemic control on cognitive function. Diabetes Care. 1996:19:656-8. 8725868.

Luijf YM, JH DV, Zwinderman K, Leelarathna L, Nodale M, Caldwell K, Kumareswaran K, Elleri D, Allen JM, Wilinska ME, Evans ML, Hovorka R, Doll W, Ellmerer M, Mader JK, Renard E, Place J, Farret A, Cobelli C, Del Favero S, Dalla Man C, Avogaro A, Bruttomesso D, Filippi A, Scotton R, Magni L, Lanzola G, Di Palma F, Soru P, Toffanin C, De Nicolao G, Arnolds S, Benesch C, Heinemann L. AP@home Consortium. Day and night closed-loop control in adults with Type 1 Diabetes: A comparison of two closed-loop algorithms driving continuous subcutaneous insulin infusion versus patient selfmanagement. Diabetes Care. 2013;36:3882-7.

Ly TT, Breton MD, Keith-Hynes P, De Salvo D, Clinton P, Benassi K, Mize LB, Chernavvsky DR, Place J, Wilson DM, Kovatchev BP, Buckingham BA. Overnight glucose control with an automated, unified safety system in children and adolescents with type 1 diabetes at diabetes camp. Diabetes Care. 2014;37:2310-6. https://doi.org/10.2337/dc14-0147.

Ly TT, Nicholas JA, Retterath A, Lim EM, Davis EA, Jones TW. Effect of sensoraugmented insulin pump therapy and automated insulin suspension vs. standard insulin pump therapy on hypoglycemia in patients with type 1 diabetes: a randomized clinical trial. JAMA. 2013;310:1240-7.

Magni L, Raimondo F, Bossi L, Dalla Man C, De Nicolao G, Kovatchev BP, Cobelli C. Model predictive control of type 1 diabetes: an in silico trial. J Diabetes Sc Technol. 2007;1:804-12.

Marliss EB, Murray FT, Stokes EF, Zinman B, Nakhooda AF, Denoga A, Leibel BS, Albisser AM. Normalization of glycemia in diabetics during meals with insulin and glucagon delivery by the artificial pancreas. Diabetes. 1977;26:663-72.

Mastrototaro JJ. The MiniMed Continuous Glucose Monitoring System. Diabetes Technol Ther. 2000;2(Sup 1):S-13-8.

McGarraugh G, Bergenstal R. Detection of hypoglycemia with continuous interstitial and traditional blood glucose monitoring using the FreeStyle navigator continuous glucose monitoring system. Diabetes Technol Ther. 2009:11:145-50.

Mirouze J, Selam JL, Pham TC, Cavadore D. Evaluation of exogenous insulin homeostasis by the artificial pancreas in insulin-dependent diabetes. Diabetologia. 1977;13:273-8.

Nauck M, Stöckmann F, Ebert R, Creutzfeldt W. Reduced incretin effect in type 2 (non-insulin-dependent) diabetes. Diabetologia. 1986b;29(1):46-52.

Nauck MA, Homberger E, Siegel EG, Allen RC, Eaton RP, Ebert R, Creutzfeldt W. Incretin effects of increasing glucose loads in man calculated from venous insulin and C-peptide responses. J Clin Endocrinol Metab. 1986a;63(2):492-8.

Nimri R, Danne T, Kordonouri O, Atlas E, Bratina N, Biester T, Avbelj M, Miller S, Muller I, Phillip M, Battelino T. The "glucositter" overnight automated closed loop system for type 1 diabetes: a randomized crossover trial. Pediatr Diabetes. 2013;14:159-67.

O'Grady MJ, Retterath AJ, Keenan DB, Kurtz N, Cantwell M, Spital G, Kremliovsky MN, Roy A, Davis EA, Jones TW, Ly TT. The use of an automated, portable, glucose control system for overnight glucose control in adolescents and young adults with type 1 diabetes. Diabetes Care. 2012;35(11):2182-7. https://doi.org/10.2337/dc12-0761.

Owens C, Zisser H, Jovanovic L, Srinivasan B, Bonvin D, Doyle FJ 3rd. Run-to-run control of glucose concentrations for people with type 1 diabetes mellitus. IEEE Trans Biomed Eng. 2006;53:996-1005.

Palerm CC, Zisser H, Bevier WC, Jovanovic L, Doyle FJ 3rd. Prandial insulin dosing using run-to-run control: application of clinical data and medical expertise to define a suitable performance metric. Diabetes Care. 2007:30:1131-6.

Parker RS, Doyle FJ 3rd, Peppas NA. A model-based algorithm for blood glucose control in type I diabetic patients. IEEE Trans Biomed Eng. 1999;48:148-57.

Parker RS, Doyle FJ 3rd, Peppas NA. The intravenous route to blood glucose control. IEEE Eng Med Biol. 2001;20:65-73.

Patek SD, Magni L, Dassau E, Karvetski CH, Toffanin C, DeNicolao G, DelFaverokS BM, Dalla Man C, Renard E, Zisser H, Doyle FJ III, Cobelli C, Kovatchev BP. Modular closed-loop control of diabetes. Transactions on Biomedical Engineering. 2012;59:2986-99.

Peyser TA, Nakamura K, Price D, et al. Hypoglycemia accuracy and improved low glucose alerts of the latest Dexcom G4 platinum continuous glucose monitoring system. Diabetes Technol Ther. 2015;17:548-54. https://doi.org/ 10.1089/dia.2014.0415.

Pfeiffer EF, Thum C, Clemens AH. The artificial beta cell-a continuous control of blood sugar by external regulation of insulin infusion (glucose controlled insulin infusion system). Horm Metab Res. 1974;6:339-42.

Phillip M, Battelino T, Atlas E, Kordonouri O, Bratina N, Miller S, Biester T, Stefanija MA, Muller I, Nimri R, Danne T. Nocturnal glucose control with an artificial pancreas at a diabetes camp. N Engl J Med. 2013;368:824-33.

Pickup JC, Keen H, Parsons JA, Alberti KG. Continuous subcutaneous insulin infusion: an approach to achieving normoglycaemia. Br Med J. 1978;1:204-7.

Place J, Robert A, Ben Brahim N, Keith-Hynes P, Farret A, Pelletier MJ, Buckingham B, Breton M, Kovatchev BP, Renard E. DiAs web monitoring: a real-time remote monitoring system designed for artificial pancreas outpatient trials. J Diabetes Sci Technol. 2013;7:1427-35.

Rebrin K, Steil GM. Can interstitial glucose assessment replace blood glucose measurements? Diabetes Technol Ther. 2000;2:461-72.

Rebrin K, Steil GM, van Antwerp WP, Mastrototaro JJ. Subcutaneous glucose predicts plasma glucose independent of insulin: implications for continuous monitoring. Am J Physiol Endocrinol Metab. 1999;277:E561-71.

Reddy M, Herrero P, El Sharkawy M, Pesl P, Jugnee N, Thomson H, Pavitt D, Toumazou C, Johnston D, Georgiou P, Oliver N. Feasibility study of a bioinspired artificial pancreas in adults with type 1 diabetes. Diabetes Technol Ther. 2014;16(9):550-7. https://doi.org/10.1089/dia.2014.0009.

Reichard P, Phil M. Mortality and treatment side effects during long-term intensified conventional insulin treatment in the Stockholm diabetes intervention study. Diabetes. 1994;43:313-7. 8288056.

Renard E, Cobelli C, Kovatchev BP. Closed loop developments to improve glucose control at home. Diabetes Res Clin Pract. 2013a;102:79-85.

Renard E, Cobelli C, Zisser H, Kovatchev BP. Artificial pancreas goes outpatient: a new diabetes ecosystem. J Diabetes Sci Technol. 2013b;7:1411-5.

Renard E, Farret A, Kropff J, Bruttomesso D, Messori M, Place J, Visentin R, Calore R, Toffanin C, Di Palma F, Lanzola G, Galasso S, Avogaro A, Keith-Hynes P, Kovatchev BP, Del Favero S, Cobelli C, Magni L, HJ DV, AP@home Consortium. Day and night closed loop glucose control in patients with type 1 diabetes under free-living conditions: comparison of a single-arm, 1-month experience to results of a previously reported feasibility study of evening and night at home. Diabetes Care. 2016;39:1151-60.

Renard $\mathrm{E}$ et al. Reduction of hyper- and hypoglycemia during two months with a wearable artificial pancreas from dinner to breakfast in patients with Type 1 Diabetes. American Diabetes Association 75 ${ }^{\text {th }}$ Scientific Sessions 2015.

Renard EM, Farret A, Place J, Cobelli C, Kovatchev BP, Breton MD. Closed-loop insulin delivery using subcutaneous infusion and glucose sensing, and equipped with a dedicated safety supervision algorithm, improves safety of glucose control in Type 1 Diabetes. Diabetologia. 2010;53(Suppl 1):S25.

Russell SJ, El-Khatib FH, Nathan DM, Magyar KL, Jiang J, Damiano ER. Blood glucose control in type 1 diabetes with a bihormonal bionic endocrine pancreas. Diabetes Care. 2012;33:2148-55.

Russell SJ, El-Khatib FH, Sinha M, Magyar KL, McKeon K, Goergen LG, Balliro C, Hillard MA, Nathan DM, Damiano ER. Outpatient glycemic control with a bionic pancreas in type 1 diabetes. N Engl J Med. 2014;371(4):313-25. 24931572. https://doi.org/10.1056/NEJMoa1314474.

Salzsieder E, Albrecht G, Fischer U, Freyse EJ. Kinetic modeling of the glucoregulatory system to improve insulin therapy. IEEE Trans Biomed Eng. 1985; 32:846-55.

Santiago JV, Clemens AH, Clarke WL, Kipnis DM. Closed-loop and open-loop devices for blood glucose control in normal and diabetic subjects. Diabetes. 1979;28:71-84.

Schiavon M, Dalla Man C, Kudva YC, Basu A, Cobelli C. Quantitative estimation of insulin sensitivity in type 1 diabetic subjects wearing a sensor-augmented insulin pump. Diabetes Care. 2014;37:1216-23.

Sherr JL, Cengiz E, Palerm CC, Clark B, Kurtz N, Roy A, Carria L, Cantwell M, Tamborlane W, Weinzimer SA. Reduced hypoglycemia and increased time in target using closed-loop insulin delivery during nights with or without antecedent afternoon exercise in type 1 diabetes. Diabetes Care. 2013;36:2909-14.

Shichiri M, Kawamori R, Yamasaki Y, Inoue M, Shigeta Y, Abe H. Computer algorithm for the artificial pancreatic beta cell. Artif Organs. 1978; 2(Suppl):247-50.

Sorensen JT. A physiologic model of glucose metabolism in man and its use to design and assess improved insulin therapies for Diabetes. [Ph.D. dissertation]. Dept Chemical Engineering, MIT, 1985. 
Steil GM, Rebrin K, Darwin C, Hariri F, Saad MF. Feasibility of automating insulin delivery for the treatment of type 1 diabetes. Diabetes. 2006;55:3344-50.

Steil GM, Rebrin K, Hariri F, Jinagonda S, Tadros S, Darwin C, Saad MF. Interstitial fluid glucose dynamics during insulin-induced hypoglycaemia. Diabetologia. 2005;48:1833-40

Stout PJ, Racchini JR, Hilgers ME. A novel approach to mitigating the physiological lag between blood and interstitial fluid glucose measurements. Diabetes Technol Ther. 2004;6:635-44.

Tamborlane WV, Sherwin RC, Genel M, Felig P. Reduction to normal of plasma glucose in juvenile diabetes by subcutaneous administration of insulin with a portable infusion pump. NEJM. 1979:300:573-8.

Tauschmann M, et al. Day-and-night hybrid closed-loop insulin delivery in adolescents with type 1 diabetes: a free-living, Randomized Clinical Trial. Diabetes Care. 2016;39:1168-74.

Thabit H, Lubina-Solomon A, Stadler M, Leelarathna L, Walkinshaw E, Pernet A, Allen JM, labal A, Choudhary P, Kumareswaran K, Nodale M, Nisbet C, Wilinska ME, Barnard KD, Dunger DB, Heller SR, Amiel SA, Evans ML, Hovorka R. Home use of closed-loop insulin delivery for overnight glucose control in adults with type 1 diabetes: a 4-week, multicentre, randomised crossover study. Lancet Diabetes Endocrinol. 2014;2:701-9.

The Diabetes Control and Complications Trial Research Group. The effect of intensive treatment of diabetes on the development and progression of long-term complications of insulin-dependent diabetes mellitus. N Engl J Med. 1993;329:978-86. 8366922.

The Diabetes Control and Complications Trial Research Group. Hypoglycemia in the diabetes control and complications trial. Diabetes. 1997;46:271-86. 900705.

The Diabetes Research in Children Network (DirecNet) Study Group. The accuracy of the Guardian ${ }^{\oplus}$ RT continuous glucose monitor in children with Type 1 Diabetes. Diabetes Tech Ther. 2008;10:266-72.

The Juvenile Diabetes Research Foundation Continuous Glucose Monitoring Study Group. Continuous glucose monitoring and intensive treatment of type 1 diabetes. N Engl J Med. 2008;359:1464-76.

UK Prospective Diabetes Study Group (UKPDS). Intensive blood-glucose control with sulphonylureas or insulin compared with conventional treatment and risk of complications in patients with type 2 diabetes. Lancet. 1998;352: 837-53. 9742976

Viceconti M, Cobelli C, Haddad T, Himes A, Kovatchev BP, Palmer M. In silico assessment of biomedical products: the conundrum of rare but not so rare events in two case studies. J Engineering in Medicine. 2017;231:455-66.

Weinzimer SA, Steil GM, Swan KL, Dziura J, Kurtz N, Tamborlane W. Fully automated closed-loop insulin delivery versus semi-automated hybrid control in pediatric patients with type 1 diabetes using an artificial pancreas. Diabetes Care. 2008;31:934-9.

Wentholt IME, Hart AAM, Hoekstra JBL, DeVries JH. Relationship between interstitial and blood glucose in type 1 diabetes patients: delay and the push-pull phenomenon revisited. Diabetes Technol Ther. 2004;9:169-75.

White NH, Skor DA, Cryer PE, Levandoski L, Santiago JV. Identification of type I diabetic patients at increased risk for hypoglycemia during intensive therapy. N Engl J Med. 1983;308:485-91.

Wientjes K, Schoonen AJ. Determination of time delay between blood and interstitial adipose tissue glucose concentration change by microdialysis in healthy volunteers. Int J Artif Organs. 2001;24:884-9.

Zisser H, Dassau E, Bevier W, Harvey R, Percival MW, Grosman B, Seborg D, Jovanovič L, Doyle FJ 3rd. Initial evaluation of a fully automated artificial pancreas. Diabetes. 2011;60(Supl 1):A41 Proceedings of the 71st American Diabetes Association meeting, San Diego, CA.

Zisser H, Jovanovic L, Doyle FJ 3rd, Ospina P, Owens C. Run-to-run control of meal-related insulin dosing. Diab Technol Ther. 2005;7:48-57.

Zisser H, Renard E, Kovatchev BP, Cobelli C, Avogaro A, Nimri E, Magni L, Buckingham B, Chase HP, Doyle FJ III, Lum J, Calhoun P, Kollman C, Dassau E, Farret A, Place J, Breton M, Anderson SM, Dalla Man C, Del Favero S, Bruttomesso B, Filippi A, Scotton R, Phillip M, Atlas E, Muller I, Miller S, Toffanin C, Raimondo D, De Nicolao G, and Beck RW for the Control to Range Study Group. Multicenter closed-loop insulin delivery study points to challenges for keeping blood glucose in a safe range by a control algorithm in adults and adolescents with Type 1 Diabetes from various sites. Diabetes Technol Ther. 2014;16:613-22. https://doi.org/10.1089/dia.2014.0066.

\section{Ready to submit your research? Choose BMC and benefit from:}

- fast, convenient online submission

- thorough peer review by experienced researchers in your field

- rapid publication on acceptance

- support for research data, including large and complex data types

- gold Open Access which fosters wider collaboration and increased citations

- maximum visibility for your research: over $100 \mathrm{M}$ website views per year

At BMC, research is always in progress.

Learn more biomedcentral.com/submissions 